\title{
ANALISIS PENGARUH CAPITAL ADEQUACY RATIO (CAR), LOAN TO DEPOSIT RATIO (LDR), DAN BIAYA OPERASIONAL DIBANDINGKAN PENDAPATAN OPERASIONAL (BOPO) TERHADAP RETURN ON ASSET (ROA) PADA BANK UMUM SYARIAH DI INDONESIA PERIODE 2015-2017
}

\author{
Wisnu Adi Wibowo *) \\ Nina Woelan Soebroto **) \\ Embun Duriany Soemarso **)
}

\begin{abstract}
This study aims to analyze the influence of Ratio Capital Adequacy Ratio (CAR), Loan to Deposit Ratio (LDR) and Operational Income Cost Effect (BOPO) partially or simultaneously to Return On Assets (ROA) at Bank Umum Syariah in Indonesia., The period 2015-2017.

The data used in this study obtained from the quarterly financial reports through the website. Population and sample in this research is Bank Syariah Mandiri, Bank Mega Syariah and Bank BNI Syariah. The results of hypothesis testing using multiple linear regression analysis using SPSS 16.

The result of determination coefficient shows the result of 0,774 or 77,4\% of variable Return On Assets (ROA) influenced by Capital Adequacy Ratio (CAR), Loan to Deposit Ratio $(L D R)$ and Operational Income Cost Effect (BOPO), the remaining 22,6\% is influenced by other factors. The results of the F test or simultaneously Capital Adequacy Ratio (CAR), Loan to Deposit Ratio (LDR) and Operational Income Cost Effect (BOPO) together have a significant effect on Return On Assets (ROA). While t test or partially, Operational Income Cost Effect (BOPO) have significant influence to Return On Assets (ROA) while Capital Adequacy Ratio (CAR) and Loan to Deposit Ratio (LDR) has no significant effect to Return On Assets (ROA) on Bank Umum Syariah in Indonesia Period 2015-2017.
\end{abstract}

Keywords: Return On Assets (ROA), Capital Adequacy Ratio (CAR), Loan to Deposit Ratio (LDR) and Operational Income Cost Effect (BOPO)

*) Mahasiswa Tugas Akhir Prodi Keuangan dan Perbankan, Jurusan Akuntansi, Politeknik Negeri Semarang

**) Dosen Jurusan Akuntansi, Politeknik Negeri Semarang

\section{PENDAHULUAN}

\section{Latar Belakang Masalah}

Rasio profitabilitas adalah salah satu rasio keuangan yang dapat digunakan untuk mengukur efektifitas perusahaan dalam memperoleh laba, atau dengan kata lain profitabilitas merupakan rasio yang menunjukan kemampuan perusahaan untuk menghasilkan laba dari kegiatan operasionalnya. Rasio profitabilitas yang digunakan adalah Return On Assets (ROA), karena rasio ini digunakan untuk mengukur kemampuan manajemen bank dalam mengelola aktiva yang dimilikinya untuk memperoleh keuntungan (laba) secara keseluruhan. Bank Indonesia lebih mengutamakan nilai profitabilitas suatu bank yang di ukur dengan aset yang 
dananya sebagian besar berasal dari simpanan masyarakat, sehingga Return On Assets (ROA) lebih mewakili dalam dalam mengukur tingkat profitabilitas perbankan Return On Assets (ROA) memfokuskan kemampuan bank untuk memperoleh earning dalam operasi perbankan, sedangkan Return On Equity (ROE) hanya mengukur return yang diperoleh dari investasi dari pemilik perusahan dalam bisnis tersebut.

Menurut Dendawijaya (2009:12) Retrun On Assets (ROA) penting bagi lembaga bank sebab digunakan untuk mengukur kemampuan manajemen efektifitas perusahaan di dalam memperoleh keuntungan secara keseluruhan. Semakin besar Return On Assets (ROA) suatu bank, semakin besar pula tingkat keuntungan yang dicapai bank tersebut dan semakin baik pula posisi bank tersebut dari segi pengelolaan aset.

\section{Tabel 1}

Data Pertumbuhan Return On Assets (ROA) Bank Syariah Periode 2015 - 2017 (dalam Persen (\%))

\begin{tabular}{|c|c|c|c|c|c|}
\hline \multicolumn{7}{|c|}{ Perkembangan ROA bank syariah } \\
\hline Tahun & Maret & Juni & September & Desember & Rata-Rata \\
\hline 2015 & 0.27 & 0.37 & 0.47 & 0.76 & 0.47 \\
\hline 2016 & 2.36 & 1.81 & 1.59 & 1.55 & 1.83 \\
\hline 2017 & 1.27 & 1.23 & 1.18 & 1.15 & 1.21 \\
\hline
\end{tabular}

Sumber : Laporan keuangan bank syariah (Bank Syariah Mandiri, Bank Mega Syariah \& Bank BNI Syariah) 2015-2017 yang diolah.

Tabel 1 menunjukkan bahwa Return On Assets (ROA) tahun 2015 sebesar $0.47 \%$ dan pada tahun 2016 meningkat menjadi 1.83\% dan pada tahun 2017 mengalami penurunan menjadi 1.21\%. Data tersebut menggambarkan bahwa Return On Assets bank syariah memiliki kinerja keuangan yang kurang baik sehingga menyebabkan Return On Assets menurun. Sebenarnya, Return On Assets (ROA) dapat ditingkatkan dengan adanya analisis dari faktorfaktor internal bank yang mempengaruhi Return On Assets, yaitu Capital Adequacy Ratio (CAR), Loan to Deposit Ratio (LDR) dan Biaya Operasional dibandingkan Pendapatan Operasional (BOPO). 


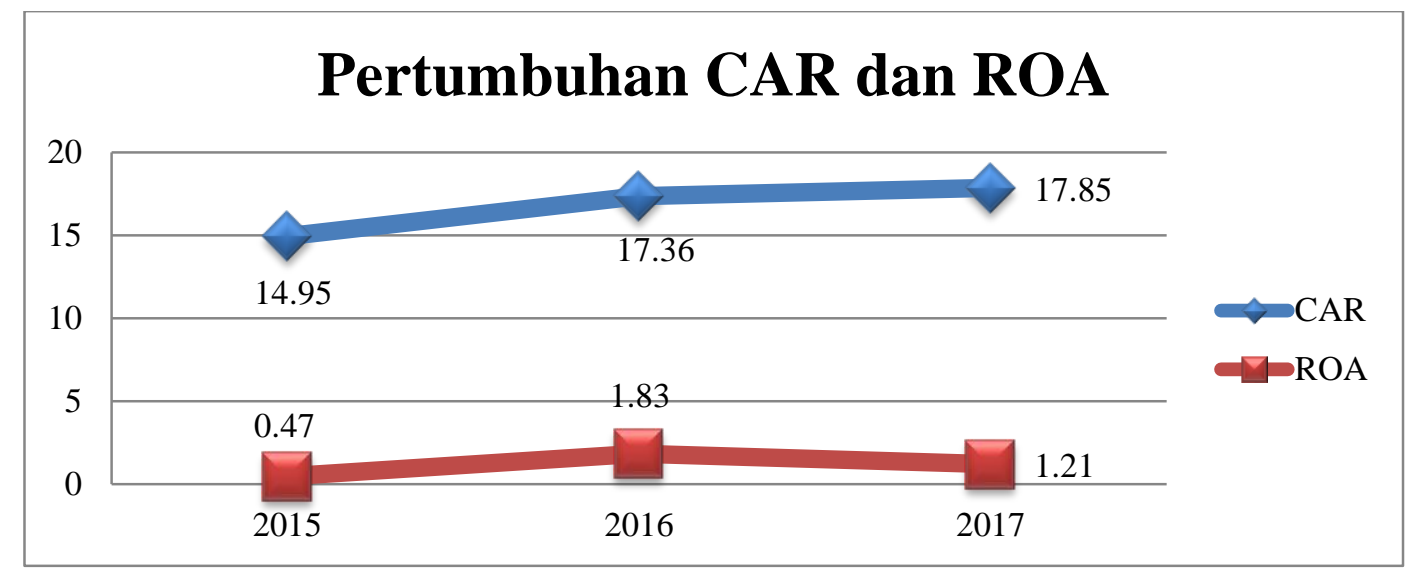

\section{Gambar 1}

Data Pertumbuhan CAR dan ROA Bank Syariah Periode 2015 - 2017 (Dalam Persen (\%))

Sumber: Laporan keuangan bank syariah (Bank Syariah Mandiri, Bank Mega Syariah \& Bank BNI Syariah) 2015-2017 yang diolah.

Gambar 1 menunjukkan bahwa selama tahun 2015 dan 2016 kenaikan angka Capital Adequacy Ratio (CAR) diikuti dengan naiknya Return On Assets (ROA) bank syariah, menunjukkan adanya hubungan searah atau positif. Pada tahun 2017 CAR mengalami kenaikan menjadi 17,85\% dari tahun 2016. Dilihat dari kenaikan CAR diikuti penurunan ROA pada tahun 2017 sebesar 0,62\% dari tahun sebelumnya sebesar 1,46\%. Meskipun grafik diatas menunjukkan kenaikan CAR, bersamaan dengan penurunan ROA, namun tidak dapat diambil kesimpulan secara langsung bahwa CAR berpengaruh terhadap ROA.

Faktor pengaruh kedua yaitu Loan to Deposit Ratio (LDR) menurut Simorangkir (2004:147), LDR dinyatakan sebagai “Loan to Deposit Ratio merupakan perbandingan antara kredit yang diberikan dengan dana pihak ketiga, termasuk pinjaman yang diterima tidak termasuk pinjaman sub ordinasi”. LDR menyatakan seberapa jauh kemampuan bank membayar kembali penarikan yang dilakukan nasabah deposan dengan mengandalkan kredit yang diberikan sebagai sumber likuiditasnya. Semakin tinggi rasio ini, semakin rendah pula kemampuan likuiditas bank yang bersangkutan. Rasio yang tinggi menunjukan bahwa suatu bank meminjamkan seluruh dananya (loan-up) atau relatif tidak likuid (illiquid). Sebaliknya rasio yang rendah menunjukan bank yang likuid dengan kelebihan kapasitas dana yang siap untuk dipinjamkan. Hal ini karena jumlah dana yang diperlukan untuk membiayai kredit menjadi semakin besar (dendawijaya, 2009:116). Untuk melihat pertumbuhan LDR bank syariah dapat dilihat dalam gambar 1.3. 


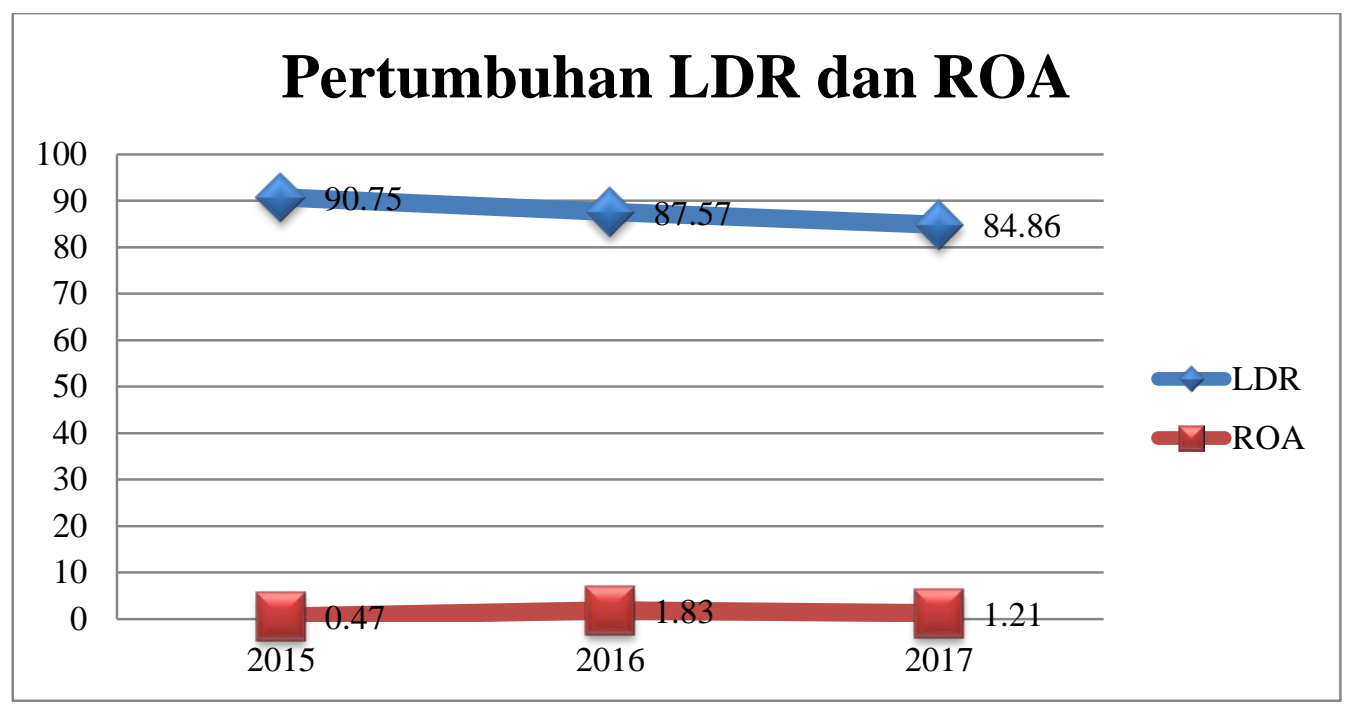

\section{Gambar 2}

Data Pertumbuhan LDR dan ROA Bank Syariah Periode 2015 - 2017 (Dalam Persen (\%)) Sumber: Laporan keuangan bank syariah (Bank Syariah Mandiri, Bank Mega Syariah \& Bank BNI Syariah) 2015-2017 yang diolah.

Gambar 2 menunjukkan bahwa penurunan LDR terjadi selama periode 20152017,dimana LDR pada tahun 2015 sebesar 90,75\% turun menjadi 87,57\% pada tahun 2016 dan kembali turun menjadi $84,86 \%$ pada tahun 2017. Sedangkan pada sisi ROA mengalami peningkatan selama periode 2015 - 2016 sebesar 1,36\%, namun pada tahun 2017 ROA turun menjadi $1,21 \%$ dimana adanya hubungan searah atau positif antara LDR dan ROA pada tahun 2017. Meskipun grafik tersebut menunjukkan kecenderungan, bahwa penurunan LDR bersamaan dengan penurunan ROA, namun tidak dapat diambil kesimpulan secara langsung bahwa LDR berpengaruh terhadap ROA.

Faktor internal ketiga adalah Biaya Operasional dibandingkan Pendapatan Operasional (BOPO) adalah merupakan rasio antara biaya operasi terhadap pendapatan operasi. Biaya operasi merupakan biaya yang dikeluarkan oleh bank dalam rangka menjalankan aktivitas usaha utamanya seperti biaya bunga, biaya pemasaran, biaya tenaga kerja dan biaya operasional lainnya. Semakin kecil rasio ini berarti semakin efisien biaya operasional yang dikeluarkan bank yang bersangkutan (usman, 2016). Untuk melihat pertumbuhan BOPO bank syariah dapat dilihat dalam gambar 1.4: 


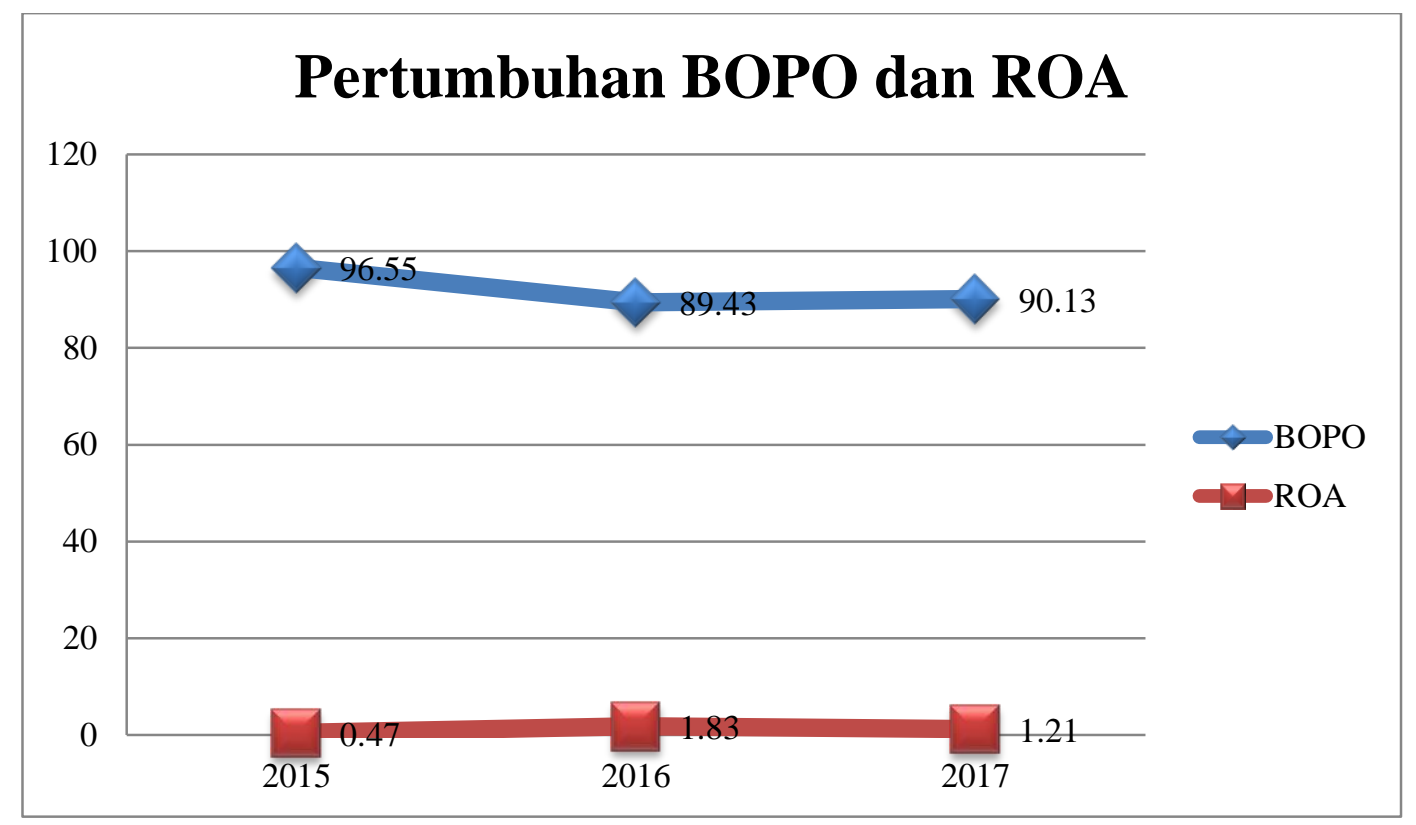

\section{Gambar 3}

Data Pertumbuhan BOPO dan ROA Bank Syariah Periode 2015 - 2017 (Dalam Persen (\%)) Sumber: Laporan keuangan bank syariah (Bank Syariah Mandiri, Bank Mega Syariah \& Bank BNI Syariah) 2015-2017 yang diolah.

Gambar 3 menunjukkan bahwa pada tahun 2016 terjadi penurunan BOPO sebesar 7,12\% dan pada tahun 2017 BOPO meningkat menjadi 90,13\%. Selain itu terdapat kenaikan ROA pada tahun 2016 sebesar 1,36\%, kemudian turun kembali menjadi 1,21\% pada tahun 2017. Kenaikan pada BOPO dan diikuti dengan adanya penurunan dari Return On Assets (ROA) pada tahun 2017 sebesar 0,62\% dari tahun 2016 maka bank syariah dapat dikategorikan tidak efisien dalam menjalankan operasionalnya.

\section{Rumusan Masalah}

Berdasarkan dari latar belakang penelitian yang telah disusun, maka permasalahan yang diangkat dalam penelitian ini diantaranya adalah apakah CAR, LDR dan BOPO secara simultan berpengaruh signifikan terhadap ROA pada bank syariah periode 2015 - 2017. Dan apakah CAR, LDR, BOPO secara parsial berpengaruh signifikan terhadap ROA pada bank syariah periode $2015-2017$. 


\section{KAJIAN TEORI}

\section{Jenis - Jenis Bank}

\section{Bank Berdasarkan Fungsinya}

Menurut Undang-Undang Pokok Perbankan Nomor 7 Tahun 1992 dan ditegaskan lagi dengan keluarnya Undang-Undang RI Nomor 10 Tahun 1998 dalam Kasmir (2011:19-20) maka jenis perbankan berdasarkan fungsinya terdiri dari :
a. Bank Umum
b. Bank Perkreditan Rakyat (BPR)

\section{Bank Berdasarkan Kepemilikan}

Menurut Kasmir (2011:20-21) jenis bank berdasarkan kepemilikan adalah sebagai berikut:
a. Bank Milik Pemerintah
b. Bank Milik Swasta Nasional
c. Bank Milik Koperasi
d. Bank Milik Asing
e. Bank Milik Campuran

\section{Bank Berdasarkan Modal Inti yang Dimiliki}

Menurut peraturan Bank Indonesia Nomor 14/26/PBI/2012 Tanggal 27 desember 2012 tentang kegiatan usaha dan jarinan kantor berdasarkan modal dan jaringan kantor berdasarkan modal inti bank. Bank di kelompokan menjadi 4 (empat) BUKU, yaitu:
a. Bank Umum Kegiatan Usaha (BUKU) 1
b. Bank Umum Kegiatan Usaha (BUKU) 2
c. Bank Umum Kegiatan Usaha (BUKU) 3
d. Bank Umum Kegiatan Usaha (BUKU) 4

\section{Return On Assets (ROA)}

Return On Assets (ROA) digunakan sebagai indikator ukuran kinerja keuangan dan dijadikan sebagai variabel dependen karena ROA digunakan untuk mengukur efektifitas perusahaan didalam menghasilkan keuntungan dengan memanfaatkan aktiva yang dimilikinya. Semakin tinggi laba yang dihasilkan, maka semakin tinggi pula ROA, hal itu berarti bahwa perusahaan semakin efektif dalam penggunaan aktiva untuk menghasilkan keuntungan (Priyanto, 2014).

Menurut SE BI No. 13/24/DPNP 25 oktober 2011, tujuan ROA adalah mengukur keberhasilan manajemen dalam menghasilkan laba. Semakin kecil rasio ini maka dapat terlihat 
kurangnya kemampuan manajemen bank dalam hal mengelola aktiva untuk meningkatkan pendapatan dan menekan biaya, sehingga dapat diartikan apabila kinerja ROA semakin tinggi maka bank secara manajemen semakin mampu mengelola aktiva dalam memperoleh pendapatan dan atau menekan penggunaan biaya.

\section{Capital Adequacy Ratio (CAR)}

Capital Adequacy Ratio (CAR) adalah rasio kinerja bank untuk mengukur kecukupan modal yang dimiliki bank untuk menunjang aktiva yang mengandung atau menghasilkan risiko, misalnya kredit yang diberikan (Dendawijaya,2000:122)

Capital Adequacy Ratio (CAR) merupakan rasio kecukupan modal bank dalam kemampuan mempertahankan modal yang mencukupi untuk menutup kemungkinan kerugian dalam penyaluran kredit. Besarnya modal suatu bank, akan mempengaruhi tingkat kepercayaan masyarakat terhadap kinerja bank. Hal ini menunjukan bahwa semakin tinggi CAR semakin baik pula kinerja bank.

\section{Loan to Deposit Ratio (LDR)}

Loan to Deposit Ratio merupakan rasio untuk mengukur komposisi jumlah kredit yang diberikan dibandingkan dengan modal sendiri yang digunakan. Besarnya Loan to Deposit Ratio menurut peraturan pemerintah maksimum 110\% (Kasmir, 2012:219)

Loan to Deposit Ratio merupakan kemampuan bank dalam membayar kembali penarikan dana yang dilakukan deposan dengan mengandalkan kredit yang diberikan sebagai sumber likuiditasnya. Loan to Deposit Ratio (LDR) merupakan perbandingan antara kredit yang diberikan dengan dana pihak ketiga, termasuk pinjaman yang diterima, tidak termasuk pinjaman subordinasi.

\section{Biaya Operasional dibandingkan Pendapatan Operasional (BOPO)}

Biaya Operasional dibandingkan Pendapatan Operasional (BOPO) merupakan rasio antara biaya operasi terhadap pendapatan operasi. Biaya operasi merupakan biaya yang dikeluarkan oleh bank dalam rangka menjalankan aktivitas usaha utamanya seperti biaya bunga, biaya pemasaran, biaya tenaga kerja dan biaya operasi lainnya. Semakin kecil rasio ini berarti semakin efisien biaya operasional yang dikeluarkan bank yang bersangkutan (Usman, 2016). 


\section{Penelitian Terdahulu}

Tabel 2

Penelitian dari Anggrainy Putri Ayuningrum

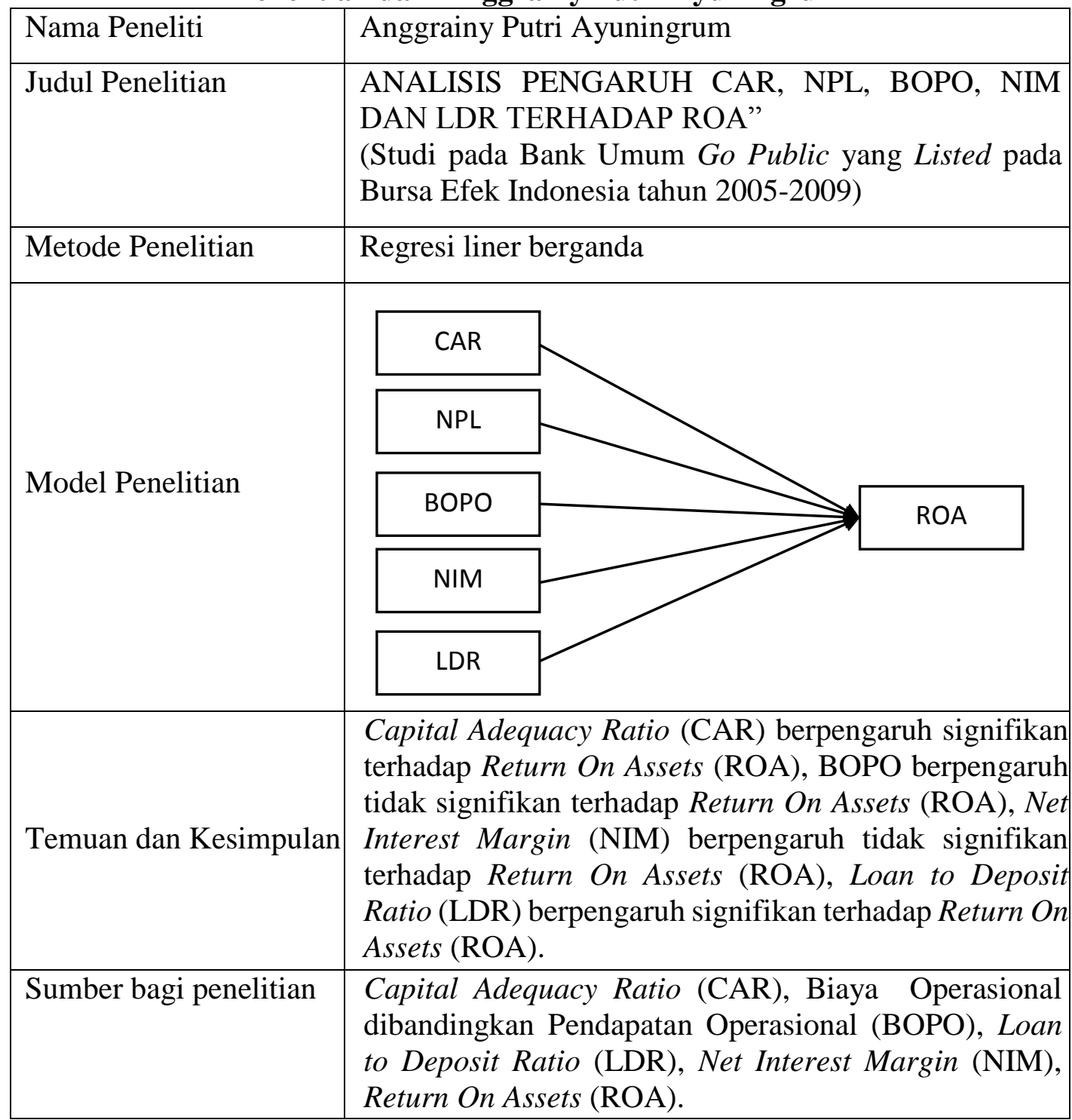

Sumber : data sekunder yang diolah 2018

\section{Kerangka Pemikiran Teoritis}

Penelitian ini dilakukan terhadap 4 variabel yang diduga berpengaruh terhadap Return On Assets (ROA) yaitu, Capital Adequacy Ratio (CAR), Loan to Deposit Ratio (LDR) dan Biaya Operasional dibandingkan Pendapatan Operasional (BOPO). Oleh karena itu kerangka pemikiran teoritis dalam penilitian ini dapat dilihat pada gambar 4: 


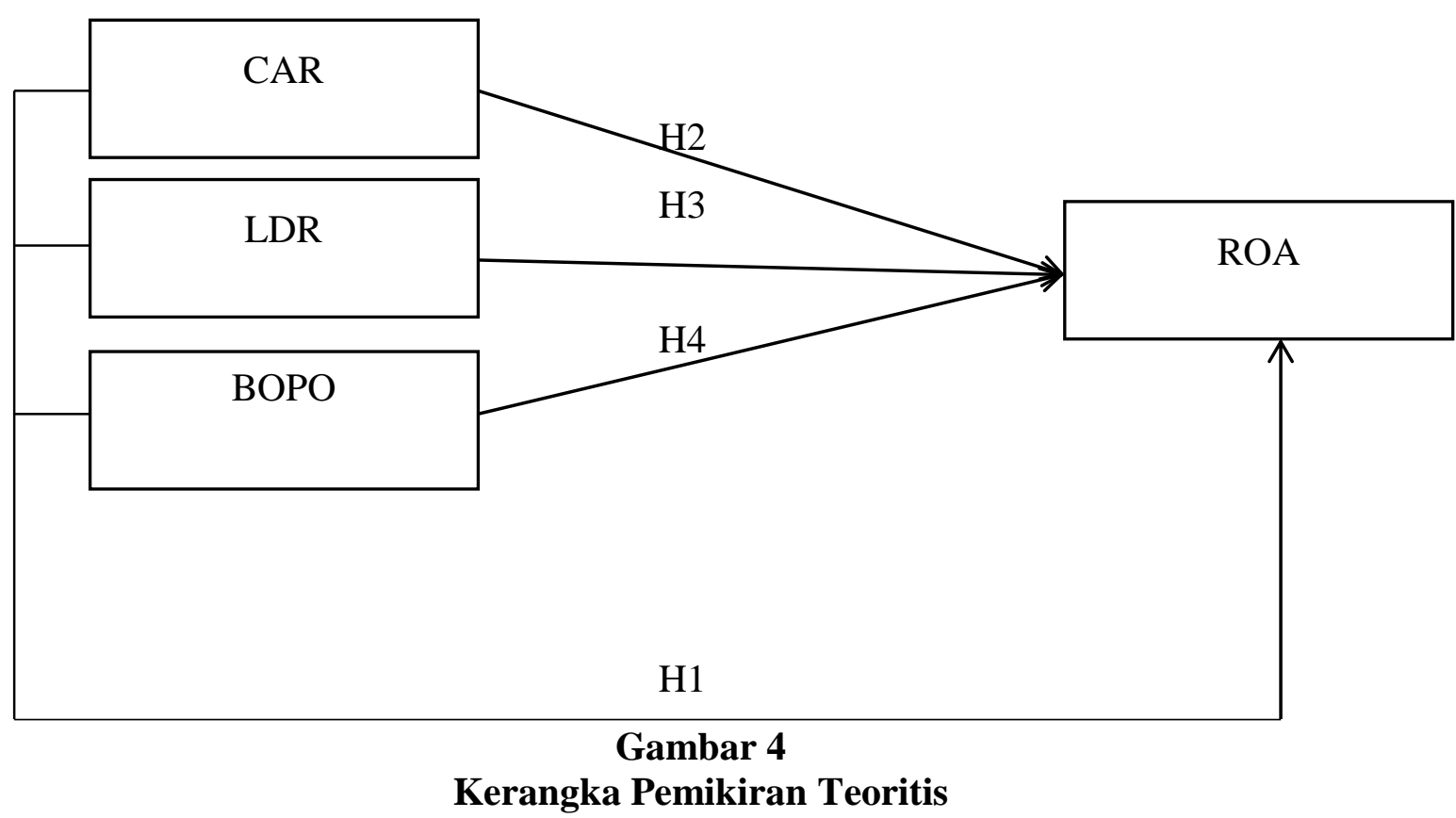

\section{METODE}

\section{Populasi dan Sampel}

Dalam penelitian ini target populasi adalah seluruh bank syariah periode 2015-2017, sedangkan untuk pengambilan sampel adalah data sekunder yang berupa laporan keuangan tahunan yang diperoleh dari website resmi Bank Syariah Mandiri, Bank Mega Syariah, dan BNI Syariah periode 2015 - 2017.

\section{Prosedur Pengumpulan dan Jenis Data}

Penelitian ini menggunakan data sekunder untuk semua variabel yaitu Capital Adequacy Ratio (CAR), Loan to Deposit Ratio (LDR), Biaya Operasional dibandingkan Pendapatan Operasional (BOPO) dan Return On Asset (ROA) pada bank syariah periode 2015 - 2017. Data sekunder dalam penelitian ini dengan variabel-variabel rasio keuangan bank syariah periode 2015-2017 bersumber dari laporan publikasi bank syariah yang dijadikan sample yang di unduh dari website resmi Bank Syariah Mandiri, Bank Mega Syariah \& Bank BNI Syariah periode $2015-2017$.

\section{HASIL DAN PEMBAHASAN}

\section{Uji Asumsi Klasik}

Uji asumsi klasik adalah uji yang harus dipenuhi sebelum dilakukan pengujian pada analisis regresi linear berganda. Uji asumsi klasik dilakukan untuk mengetahui ada tidaknya 
pelanggaran terhadap asumsi-asumsi klasik. Asumsi-asumsi klasik dalam penelitian ini meliputi uji normalitas, uji heteroskedastisitas, uji multikolinieritas, dan uji autokolerasi.

\section{Uji Normalitas}

Uji normalitas bertujuan untuk menguji apakah dalam sebuah model regresi, variabel dependen, variabel independen atau keduanya mempunyai distribusi normal ataukah tidak mempunyai distribusi normal. Hasil dari penelitian ini menunjukkan bahwa data penelitian ini mengikuti distribusi normal dikarenakan nilai ekstrim Kolmogorov-Smirnov (D) unstandardized residual adalah sebesar 1,117 dengan nilai p-value sebesar 0.164 . Nilai $\mathrm{D}<$ D* (0.05) dan p-value $>0.05$ yang berarti $H_{0}$ diterima.

\section{Uji Heteroskedastisitas}

Uji heteroskedastisitas digunakan untuk mengetahui ada atau tidaknya penyimpangan asumsi klasik heteroskedastisitas yaitu adanya ketidaksamaan varian dari residual untuk semua pengamatan pada model regresi. Hasil dari penelitian ini menunjukkan bahwa tidak dapat heteroskedastisitas dalam penelitian ini atau semua variabel independen memiliki sebaran varian yang sama atau homogen. Hal ini dapat dibuktikan bahwa variabel CAR, LDR, dan BOPO memiliki nilai signifikasi 0,102; 0,296; dan 0,205 yang semuanya di atas 0,05.

\section{Uji Multikolinieritas}

Uji multikolinieritas bertujuan untuk menguji apakah dalam model regresi ditemukan adanya korelasi yang tinggi atau sempurna antar variabel independen. Hasil dari penelitian ini dinyatakan tidak terjadi gejala multikolinieritas. Hal ini ditunjukkan bahwa CAR, LDR, dan BOPO memiliki nilai tolerance $<0,10$. Begitu juga dengan hasil perhitungan nilai VIF, tidak ada variabel independen yang memiliki nilai VIF > 10,00.

\section{Uji Autokorelasi}

Uji autokolerasi bertujuan menguji apakah dalam suatu model regresi linear ada korelasi antara kesalahan pengganggu pada periode t dengan kesalahan pada periode t-1 (sebelumnya) (Ghozali, 2005). Hasil dari penelitian ini dapat disimpulkan bahwa tidak terjadi masalah autokorelasi. Hal ini ditunjukkan dengan nilai DW $\mathrm{DW}_{\text {hitung }}$ sebesar 2,235 akan dibandingkan dengan nilai tabel dengan menggunkan derajat kepercyaan 5\% $(\alpha=0,05)$, jumlah sampel 36 data $(\mathrm{N}=36)$, dan jumlah variabel $3(\mathrm{k}=3)$. Oleh karena nilai $\mathrm{DW}_{\text {hitung lebih besar daripada batas }}$ atas 1,6539 dan lebih kecil daripada 4- $\mathrm{d}_{\mathrm{u}}=4-1,6539=2,3461$, atau: $d_{u}<d<4-d_{u} \Leftrightarrow$ $1,6708<2,235<2,3461$. 


\section{Uji Analisis Regresi}

Secara umum, analisis regresi pada dasarnya adalah studi mengenai ketergantungan variabel dependen (terikat) dengan satu atau lebih variabel independen (variabel penjelas/bebas), dengan tujuan untuk mengestimasi dan/atau memprediksi rata-rata populasi atau nilai rata-rata variabel dependen berdasarkan nilai variabel independen yang diketahui (Gujarati, 2003 dalam Ghozali, 2005). Peneliti menggunakan analisis generasi ganda, dikarenakan peneliti bermaksud meramalkan bagaimana keadaan (naik turunnya) variabel dependen (kriterium), bila dua atau lebih variabel independen sebagai prediktor dimanipulasi (dinaikturunkan nilainya).

\section{Koefisien Determinasi (Adjusted $\mathbf{R}^{2}$ )}

Koefisien determinasi $\left(\mathrm{R}^{2}\right)$ pada intinya mengukur seberapa jauh kemampuan model dalam menerangkan variasi variabel dependen (Ghozali, 2013:97). Hasil dari penelitian tersebut adalah besarnya adjusted $\mathrm{R}^{2}$ sebesar 0,774 , hal ini berarti $77,4 \%$ variasi kinerja keuangan (ROA) dapat dijelaskan oleh variasi dari tiga independen CAR, LDR, dan BOPO. Sedangkan sisanya $(100 \%-77,4 \%=22,6 \%)$ dijelaskan oleh sebab-sebab yang lain di luar model. Standard error of estimate (SEE) sebesar 0,51059.

\section{Uji F (Uji Kelayakan Model)}

Uji statistik F digunakan untuk menunjukkan apakah semua variabel bebas (independen) yang dimasukkan dalam model mempunyai pengaruh secara bersama-sama terhadap variabel terikat (dependen) (Kuncoro, 2001:98). Hasil dari penelitian ini adalah CAR, LDR, dan BOPO secara bersama - sama berpengaruh terhadap ROA, dan bentuk persamaan regresi linear sudah tepat. Hal ini ditunjukkan oleh nilai $\mathrm{F}$ adalah 40,973 dengan probabilias 0,00. Karena probabilitas jauh lebih kecil dari 0,05,

\section{Uji Signifikan Parameter Individual (Uji t)}

Uji t pada dasarnya menunjukan seberapa jauh pengaruh satu variabel penjelas secara individual dalam menerangkan variasi variabel terikat (Kuncoro, 2001). Hasil penelitian ini adalah variabel kinerja keuangan (ROA) dipengaruhi oleh CAR, LDR, dan BOPO dengan persamaan matematis $\mathrm{ROA}=10,734+0,069 \mathrm{CAR}+0,28 \mathrm{LDR}-0,144 \mathrm{BOPO}$. Hal ini dilihat dari probabilitas signifikan untuk LDR sebesar 0,127yang jauh di atas 0,05. Sedangkan CAR dan BOPO memiliki nilai signifikan dengan probabilitas 0,061 dan 0,000 yang berpengaruh signifikan pada $\alpha=10 \%$ yang terlihat dari probabilitas signifikansi di bawah 0,10 . 


\section{PENUTUP}

\section{Kesimpulan}

Berdasarkan masalah yang dibahas dalam bab sebelumnya yang menyatakan bahwa adalah apakah CAR, LDR dan BOPO secara simultan berpengaruh signifikan terhadap ROA pada bank syariah periode 2015 - 2017. Dan apakah CAR, LDR, BOPO secara parsial berpengaruh signifikan terhadap ROA pada bank syariah periode 2015 - 2017, sehingga dapat ditarik kesimpulan:

1. Berdasar hasil perhitungan statistik dengan uji $\mathrm{F}$ menunjukkan bahwa variabel Capital Adequacy Ratio (CAR), Loan to Deposit Ratio (LDR), dan Biaya Biaya Operasional dibandingkan Pendapatan Operasional (BOPO) berpengaruh positif terhadap Return On Asset (ROA).

2. Berdasar hasil perhitungan statistik dengan uji t menunjukkan bahwa variabel Capital Adequacy Ratio (CAR) tidak berpengaruh terhadap Return On Asset (ROA).

3. Berdasar hasil perhitungan statistik dengan uji t menunjukkan bahwa variabel Loan to Deposit Ratio (LDR) tidak berpengaruh terhadap Return On Asset (ROA).

4. Berdasar hasil perhitungan statistik dengan uji t menunjukkan bahwa variabel Biaya Operasional dibandingkan Pendapatan Operasional (BOPO) berpengaruh negatif terhadap Return On Asset (ROA).

\section{Keterbatasan Penelitian}

Penelitian ini terbatas pada jumlah sampel, yaitu hanya terbatas pada 3 bank devisa saja. Di samping itu rasio-rasio keuangan bank yang digunakan sebagai dasar untuk memprediksi Return On Asset (ROA) hanya terbatas pada rasio Capital Adequacy Ratio (CAR), Loan to Deposit Ratio (LDR), dan Biaya Operasional dibandingkan Pendapatan Operasional (BOPO), dimana ada dua variabel yang pengaruhnya tidak signifikan terhadap Return On Asset (ROA), yaitu Capital Adequacy Ratio (CAR) dan Loan to Deposit Ratio (LDR).

\section{Agenda Penelitian Mendatang}

Bagi peneliti selanjutnya diharapkan dapat meneliti dengan variabel-variabel lain diluar variabel Capital Adequacy Ratio (CAR), Loan to Deposit Ratio (LDR) dan Biaya Operasional dibandingkan Pendapatan Operasional (BOPO) agar memperoleh hasil yang lebih bervariatif yang dapat menggambarkan hal-hal apa saja yang dapat berpengaruh terhadap ROA. Sedangkan bagi perbankan diharapkan mampu mengoptimalkan penggunaan rasio kecukupan modal, likuiditas dan efisiensi, sehingga kesehatan bank terkontrol dari waktu ke waktu sesuai dengan Peraturan yang telah ditetapkan oleh Bank Indonesia. 


\section{DAFTAR PUSTAKA}

Abdullah, Thamrin Dan Francis Tantri. 2012. Bank Dan Lembaga Keuangan. Jakarta : PT Raja Grafindo Persada.

Aini, Nur. 2013 "Pengaruh CAR, NIM, LDR, NPL, BOPO dan Kualitas Aktiva Produktif Terhadap Perubahan Laba" (Studi Empiris Pada Perusahaan Perbankan Yang Terdapat Di Bei Periode 2009-2011). Dinamika Akuntansi, keuangan dan Perbankan. Volume 2, Nomor 1

Avrita, Risky Diba dan Irene Rini Demi Pangestuti. 2016 “Analisis Pengaruh CAR, NPL, LDR, NIM dan BOPO Terhadap Proiabilitas Bank”. E-journal undip-S1. Volume 5, Nomer 2

Ayuningrum, Anggrainy Putri. 2011. "Analisis Pengaruh CAR, NPL, BOPO, NIM dan LDR Terhadap ROA”(Studi pada Bank Umum Go Public yang Listed pada Bursa Efek Indonesia tahun 2005-2009). Tesis fakultas ekonomi dan bisnis universitas sam ratulangi.

Bank Indonesia. 1998. Undang-Undang Republik Indonesia No. 10 Tahun 1998 Tentang Perbankan. http://www.bi.go.id

Bank Indonesia. 2005. Bank Syariah : Gambaran Umum. http://www.bi.go.id/

Bank indonesia. 2015. Peraturan Bank Indonesia No. 17/II/PBI Tentang Giro Wajib Minimum Dalam Rupiah Dan Valuta Asing Bagi Bank Konvensional. http://www.bi.go.id.

Bank Indonesia. 2012. Peraturan Bank Indonesia No.14/26/PBI Tentang Kegiatan Usaha Dan Jaringan Kantor Berdasarkan Modal Inti. http://www.bi.go.id

Bank Indonesia. 2011. Peraturan Bank Indonesia No.13/24/DPNP Tentang Tata Cara Penilaian Tingkat Kesehatan Bank. http://www.bi.go.id

Bank Indonesia. 2013. Peraturan Bank Indonesia No. 15/12/PBI/2013 Tentang Kewajiban Penyediaan Modal Minimum Bank Umum. http://www.bi.go.id

Bank Mandiri Syariah. 2015. Laporan Publikasi Keuangan Triwulan. http://www.syariahmandiri.co.id/.

Bank Mandiri Syariah. 2016. Laporan Publikasi Keuangan Triwulan. http://www.syariahmandiri.co.id/.

Bank Mandiri Syariah. 2017. Laporan Publikasi Keuangan Triwulan. http://www.syariahmandiri.co.id/. 
keunis Majalah IImiah - ISSN No 2302-9315 Vol. 7 No 2 Thn VII Juli 2019

Bank Mega Syariah. 2015. Laporan Publikasi Keuangan Triwulan .http://www.megasyariah.co.id/.

Bank Mega Syariah. 2016. Laporan Publikasi Keuangan Triwulan .http://www.megasyariah.co.id/.

Bank Mega Syariah. 2017. Laporan Publikasi Keuangan Triwulan. http://www.megasyariah.co.id/.

BNI Syariah. 2015. Laporan Publikasi Keuangan Triwulan. http://www.bnisyariah.co.id/.

BNI Syariah. 2016. Laporan Publikasi Keuangan Triwulan. http://www.bnisyariah.co.id/.

BNI Syariah. 2017. Laporan Publikasi Keuangan Triwulan. http://www.bnisyariah.co.id//

Dendawijaya, Lukman. 2009. Manajemen Perbankan. Jakarta: Ghalia Indonesia.

Dewi, Pramitha Kusuma, Mulyadi, dan Abdurrahman. 2015. "Analisis Pengaruh CAR, NPL, LDR, dan NIM Terhadap Profitabilitas Perbankan". Volume 3, Nomor 1

Eng, Tan Sau. 2013. "Pengaruh NIM, BOPO, LDR, NPL dan CAR Terhadap ROA Pada Bank Internasional dan Bank Nasional Go Public 2007-2011”. Jurnal Dinamika Manajemen. Volume 1, Nomor 3 